\title{
INTERNAL DISRUPTIONS in FAMILY BUSINESS SUCCESSION: Death, Divorce, and Disability
}

\author{
ALEV M. EFENDIOGLU \\ Prof.Dr.University of San Francisco \\ EUGENE MUSCAT \\ Prof.Dr.University of San Francisco
}

\begin{abstract}
Family-owned businesses continue to form the backbone of most of the national economies. However, because of the tenuous nature of the ownership structure of most small and family businesses only one in three family businesses succeeds in making it from the first to the second generation. In addition to issues and problems they encounter when they try to undertake expected and natural transitions (e.g. retirement, etc.), these smaller businesses are particularly vulnerable to the impact of unexpected, life-altering events that affect the business owner and often the business itself. Because of the lack of availability of research studies in this area, we used real life cases and events published in numerous business publications and from our personal experiences to categorize and summarize these incidents to develop a preliminary perspective of the various impacts such changes can have on these businesses.
\end{abstract}

Keywords: Family Business, Business Succession, 


\section{Introduction}

In most of the countries, family-owned businesses continue to form the backbone of the domestic economy.According to the University of Southern Maine's Institute for Family-Owned Business (USA), 35\% of Fortune 500 companies in United States are family-controlled and family businesses account for $50 \%$ of U.S. gross domestic product. They also generate $60 \%$ of the country's employment and $78 \%$ of all new job creation. Over $30 \%$ of the Fortune 500 and $60 \%$ of all public companies in the United States are family-controlled and there are 35,000 familyowned U.S. businesses with revenues greater than $\$ 25$ million. (Poza, 2004) Even though large scale family owned businesses employ professional managers and separate family affairs from business affairs in many ways, family owned small businesses mix business and family. Their family problems and decisions are mixed with business problems and decisions. As a result, solutions to their problems are rarely pure business or pure family in nature and any attempts at complete separation are counterproductive. Furthermore, regardless of size, they face significant challenges of continuity, longevity, and ultimately success.

Generally speaking, the failure rate for all private businesses is high. According to the United States Small Business Administration's Office of Advocacy, 580,900 new businesses were launched in 2004, the most recent date available for data, while 576,200 closed. Furthermore, given that only one in three family businesses succeeds in making it from the first to the second generation, these businesses have their own inherent risks, beyond the financial and legal pressures which all businesses face. Among these characteristics is the tenuous nature of the ownership structure of most small and family businesses and their failure to transition leadership and/or ownership of the business to new generations. Even though effective succession planning can prepare these organizations for change and transition, unfortunately majority of these businesses do not necessarily avail themselves to such planning and fail to focus on issues that are important on the longer run. In addition to issues and problems they encounter when they try to undertake expected and natural transitions (e.g. retirement, etc.), these smaller businesses are particularly vulnerable to the impact of unexpected, life-altering events that affect the business owner and often the business itself, severely undermining the successful transition of leadership and/or ownership and the long-term survival of the business. 


\section{Leadership Transition/Succession in Family Businesses}

Family businesses are defined in terms of their ownership, managerial authority and outcome responsibility. Majority ownership of a family business is by one or more family members who have the managerial authority and outcome responsibility for its day to day management as well as its short and long-term strategies and its overall survival and growth over time. In some circumstances, the management team may include some people unrelated to the family business managers, and the employees may be family and/or non-family. The founder may be called by different names, including owner, manager, or senior manager. The current owners may or may not be the first generation owning this business.

Succession refers to the transfer of the management and/or the control of a business. Ownership succession focuses on who will own the business, when and how it will happen. Management succession focuses on who will run the business, what changes will occur, when will they be accountable for results and how will results be realized. Succession issues have been identified to be of great concern in family business survival (Lee, Lim, and Lim, 2003; Montgomery and Sinclair, 2000) Unfortunately, evidence suggests that the succession process in family businesses is fraught with troubles and very few of these businesses survive beyond the first generation and, even if they do, the incidence of survival diminishes with each attempted transfer. (JanjuhaJivraj and Woods, 2002; Lansberg, 1999) Fewer than $30 \%$ of family businesses survive to second generation and less than $15 \%$ survive to the third generation.

Based on their ownership structure, we have classified small businesses in three major groups. They are "multiple family members" group, "single family member" group, and "the absent family" group. The businesses that fall into the "multiple family members" group are the family businesses where the whole or majority of the family tends to be involved in the business, family members are considered to have obligations to the business, participate regularly in the firm from an early age, and are the successors of the family business. The businesses that fall into "single family member" group are family businesses where virtually no family member besides the principal is automatically involved in the business, succession does not necessarily remain in the 
family, and family obligations and participation are not expected. Finally, the businesses which can be placed in "the absent family" group are family businesses which are owned by a family but are managed professionally, without any member of the family actively participating in the business operations. In each of these different types of "family businesses", different stances of various individuals toward the family business will have significantly different implications for the dynamics involved in the succession processes. The attitudes, perspectives and positions of these individuals are generally influenced by the culture, values and outlook existing within that family and business, and these family members' attitudes, both individually and collectively, will impact and influence the transition of leadership and can act as enablers or constraints to the process. Among these personal characteristics, which may act as impediments to a successful transition, the most commonly observed ones are next generation's personal need fulfillment, career interests, personal identity, life stage, personal influence, mutual respect and understanding between generations, sibling accommodation, commitment to family business perpetuation and separation strains due to family involvement.

A study exploring the intentions of 18-to-28-year-old university students to join and take over their parents' firms found that the overall intentions of participants to join the family business are low, with 20 percent of the respondents expressing no interest in joining the family business. Two of the most important reasons reported for not joining the business were having other plans for the future and the intention of pursuing a different career path. (Stavrou, 1999) These findings are also supported by the authors' experiences with the family businesses and teaching a course called Family Business. Almost every semester since Fall 1999, when the first semester freshmen students in the Family Business class were asked "Will you work for your parents after graduation?" the responses were on the average " $60 \%$ no" and " $40 \%$ yes". These are the responses from approximately $270-300$ students since we started asking this question. These numbers did change somewhat at the time of these students' graduation, with "60\%" saying they would enter family business and $40 \%$ maintaining no desire to enter the business. This is still a significant number with no plans to continue their parents' business. Family businesses typically provide limited career growth opportunities for family members and employees given the small number of top managers and only one to three levels of management. Therefore, even a highly motivated and talented college graduate may 
have a twenty-year wait for a promotion and a true opportunity to manage even a small business.

Even if promotion and managerial opportunities exist, the family business may not provide opportunities that fit all family members' strengths or the incoming generation may have strengths not applicable to the existing family business. In their efforts to keep the business in the family, some businesses have planned to hand over the business to an offspring, even though the offspring is unqualified to take over the business. (Lee, Lim, and Lim, 2003) Even though we would very much like to think that if we have college education, especially a degree in business, we should have the necessary skills for and understanding of all types of businesses and should be able to take them over and make them a success. Unfortunately, given the unique characteristics and significant limitations associated with a family business, the knowledge and skills acquired through an undergraduate degree, even if it is in business, may not be enough to take over and successfully manage these businesses. Of course, the potential incoming managers of these businesses with education and skills in non-business related areas (e.g. humanities or sciences) face even greater challenges and may actually cause significant hardship to these fragile businesses and accelerate their demise. Organizational slack, which may exist in large businesses, is severely lacking is small family businesses and will not be available to compensate for incompetent family members or absorb the cost of mistakes made by these new managers.

If the family members' attitudes towards each other (e.g. conflicting egos) and towards the business are significantly divergent then, even under the best of conditions, serious conflicts will arise during the succession and transition of leadership. On the other hand, if there is relative homogeneity of attitudes and expectations among the family members, this congruence can have a significant positive influence on the succession planning and increase the relatively smooth transition of leadership and continued success of the family business. (Birley, Ng, and Godfrey, 1999) After interviews with family business owners, Kickham (2004) concluded that family working relationships is a very significant factor which contributes to family business survival and failure. 
The success of succession in a family business also seems to be significantly impacted by how the business is defined after the succession (e.g. post transition strategy and operations). Therefore, even under the best of the conditions, unless both the process of the transfer of the management and/or the control of the business are addressed in the succession planning and implementation, the success of such transition will be significantly jeopardized. Numerous family business succession research show that the family business successions falter when the succession doggedly perpetuates prevailing "status quo" or creates a sharp reaction against the prevailing "status quo" as the business seeks a radical differentiation from its past. If these succession outcomes are not addressed during the succession planning and implementation, the risks of a family business succession ultimately failing are increased. (Miller, et. al., 2003; Barach, et. al., 1988; Fritz, 1997) As leadership transitions from the current ownermanager to the new owner-manager, the family business should be able to change to accommodate the needs of the new leader and utilize his/her unique skills, while drawing upon the already existing successful characteristics of the family business. To overcome the negative impact of some of these differing attitudes and behaviors about the "future of business" and skill sets needed for continued success of these businesses, some criteria can be developed and used to assess each potential successor's fitness for the leadership role.

Management succession can be a process taking place over many years requiring cooperation of all people on the management team, even the family members who are not currently involved in the business in any way or a member of the current management team. The successful succession in family businesses involve planning, selection and preparation of the next generation of managers, transition in management responsibility, gradual decrease in the role of previous managers and finally discontinuation of any input by previous managers. However, because this process requires a consideration of the overall organizational needs, current and future, and because most family enterprises are driven as much by other factors, which do not necessarily have a business foundation, as these needs, the process of rational selection of the successor is not utilized as often as it should be. Unfortunately, this lack of rationality and professionalism in the succession process further endanger the success of most family businesses. 
Above presentation and discussion of succession issues assume a natural and, hopefully, a planned transition or succession of leadership. However, a family business, just like any other business, may also have to go through and experience transition (succession of leadership) due to some "unexpected life altering event" impacting the leadership (management) or the ownership of the business, and management succession can be due to a crisis. The crisis may be brought about by the death or disability of the founder, divorce, threat of departure by the heir apparent, or hiring of an outside manager in an attempt to bring about change and fix long running problems in the family business. The impact of such an event which forces an unplanned and crises based transition upon the business enterprise, will have a much greater impact, and in most cases, a significantly large and negative impact.

Unfortunately, because of the sensitivity of the topic (death, disability due to sudden major illness, and divorce), which makes it almost impossible to conduct primary research, and lack of reliable data (especially financial) on this specific sub-segment of small businesses, very few earlier research is available. In fact, our extensive searches have resulted with only one study that addresses one of our selected "life altering events", published in 2003. It utilized a proprietary database from a large National business valuation and appraisal firm and included fifty-two family businesses which experienced a "life altering event" (divorce) between 1990 and 1999. The study compared the financial characteristics of these multiple industry family businesses before and the year after the "divorce". They found that the event had a major negative impact on the business' finances (revenues down $58 \%$, gross profit down $56 \%$, profitability down $65 \%$, working capital down $65 \%$, and total equity down 68\%). (Galbraith, 2003)

Because of the lack of availability of research studies in this area, we decided to review real life cases and events published in numerous business publications and our personal experiences and dealings with family businesses which have experienced such an event (unexpected death, serious illness and divorce that involve one or more of the business owners).

The focus of our review was to test three propositions we identified as the most likely impact of these "internal disruptions" in a small familyowned business. The foundation of these propositions are based on the 
premise that "the family business is so much dependent on the characteristics the owner brings to the business that a major event impacting the owner will have major ramifications for the family owned small business" These propositions are:

1. Untimely and unexpected demise of the owner or owner's family will impact the vitality and the sustainability of the business and, in most cases, the business will cease to exist.

2. Divorce will have a significant financial impact on the size of operations and related diseconomies (reduced asset availability due to distribution, and psychological and personal impact caused by turmoil, contentiousness, and time commitments).

3. Disability will cause significant loss of assets (e.g. funds expanded to overcome the tragedy, and damage to owner's psyche, time, skills, and abilities) and will be a major threat to the survival of the business on the long run, if not immediately.

In the following sections we will categorize and summarize these published incidents and our direct experiences and first hand knowledge we have gained from working with small family-owned businesses in the United States over 20 years. We will briefly discuss the impact of these changes in the family businesses which we have classified as "multiple family members group" and "one family member group" type of a business and provide some recommendations for family businesses so that they can possibly minimize the impact of an unfortunate and unexpected "life changing event".

\section{Discussion of Findings}

Using our personal experiences and published incidents, we were able to identify thirty family businesses and have classified them based on their "business type", "ownership structure", and "event". We also looked at the impact of an unexpected "life altering event" on these businesses. Even though we did not have any concrete measures we could use in our analysis (e.g. before and after financials), we were able to evaluate the impact of the "event" by looking at the characteristics of these businesses during the transition (the turbulence and changes) and the final outcome (new steady-state after the event). We have found that, in all but one of these businesses, these events had a very negative impact on these family businesses, even bankrupting some of them. One might expect this type of an outcome in family businesses 
where there is "single ownership" (an owner without family members who can take over) but, many of the businesses we looked at were "multi-ownership" (an owner with family who can take over). As such, it was somewhat surprising to find the "event's" devastating impact on the final state of the business. Even though there are many "unexpected life changing events" (e.g. fire, earthquake, etc.), we focused on three most common ones and their impacts on the family business. They are "death", "divorce", and "disability due to serious illness". Our findings and analysis are summarized in the following tables.

As can be seen from Table 1, the "death" event has different implications for the business based on its ownership structure and on whom the event happens to. In businesses which we have classified as "single family", the family business is so much dependent on the characteristics the owner brings to the business that the untimely and unexpected demise of the owner has a devastating impact and in most likely will cease to exist. Even if there are co-owners, the loss of one creates a similar impact and, even though the business may continue to exist, its value and vitality is significantly and negatively impacted.

In businesses we have classified as "multiple family" (where there are more than one family member involved, partially or fully in the family business), the death of the owner presents yet another set of transitional problems. In these cases, the final status of the family business seems to depend upon two major factors: the transferability of the type of expertise brought to the business by the "owner/manager" and the remaining participant business owners' willingness or interest to continue with the business. Table 1 also shows that, these two factors have a significant influence and make the positive outcome (continuation of the family business) very unlikely. This was the same finding of an earlier study by Stavrou (1999), who found that 20 percent of the respondents expressing no interest in joining the family business. Our study further demonstrates that, even if these family members were already involved in the business, they see this unfortunate event as an opportunity to sell and move on to other pursuits.

The second life-altering event we identified was "divorce" and Table 2 presents our findings on impact of this event on the family business. Of course, with the "divorce" event, there is some-what longer time frame with significant discord and contentiousness among the family members who have a financial stake in the business and demands on the value of its assets. In "multiple family" businesses, because generally it is the husband and wife team who own and operate the family business, 
divorce invariably breaks up the business and can create competitors vying for the same client base and existing employees. Even though there is a significant financial impact of divorce, impacting size of operations and related diseconomies (e.g. reduced asset availability due to distribution, etc.), most of the damage is done to the business during the time while divorce process is in place. Because these married persons are also skilled participants and partners in the business and they would like to continue as business owners, they become very proactive in their efforts to keep the "good employees" in their side of the conflict and get the "valuable customers" to move to their "new" business and maintain their current relationships with the new business. The findings of the Galbraith's (2003) study, the only prior research which identifies and reports the "impact of divorce as it relates to post-divorce profitability of the business", show that there are significant reductions in revenues (down 58\%), gross profit (down 56\%), profitability (down 65\%), working capital (down 65\%), and total equity (down 68\%).

However, our findings show that, in addition to possible significant financial consequences (e.g. smaller operations, changing revenue streams, legal expenses, etc.); there are also some competitive issues that arise when a "multiple family" experiences a "divorce" of its partners. Because neither of the two partners generally wants to relocate to a completely new geographical area and acquire a brand new customer base, each pursues a predatory business practice to undermine the success and the viability of the other ex-partner (now a competitor). As the "war of roses" moves from the bedroom to the marketplace, it eventually ends up hurting both businesses. Finally, the complimentary benefits of the previously married partners will be lost, putting each of the new businesses at a competitive disadvantage against other competitors in the same market space. The findings of the National Poll by NFIB underscore the importance and possible impacts of such an event on family businesses. According to the NFIB poll, the most common ownership structure involves two people, typically husband and wife, and spouses represent about two of every three (67 percent) of partners in family businesses. (Dennis, 2002) (Table 3) 
The third life-altering event, a serious "illness based disability" of the owner or illness of family member of the owner, brings with it yet even more challenges, some of which are similar to the previously identified impacts and others which are unique. Unfortunately, insurance industry statistics show that, for multiple family businesses and for businesses with multiple partners, the small businesses are much more likely to encounter a disabling accident or illness, as compared to premature death. (Hill, 1992)

When an unexpected accident happens to the owner of a family business or a serious illness strikes the owner or someone in the owner's family, two major outcomes can be a significant loss of assets (funds expanded to overcome the tragedy) and the impact on business caused by the damage to owner's psyche. Whether it is the owner who gets disabled (due to an accident or serious illness) or someone in his/her family, the family will try to expand all the resources they can gather (including personal and business assets) to bring hospitalization, treatments, and overall relief to the disabled/injured/ill person. This impact is very clear and is a very highly probable outcome. However, what is not so clear and easily anticipated is the impact of such an event on the owners' psyche and its implications for the family business. This event's physical human consequences (e.g. long hospital stays, debilitating medications and treatments, etc.) can be long lasting and consume complete thoughts and activities of all the family members, significantly impacting the time and effort put forth for the operational activities of the business. Either of these outcomes (financial or psychological) can threaten the survival of the business on the long run, if not immediately. Our study shows that, even under the best conditions and efforts of the business owner (e.g. one owner tried to continue to manage the business after becoming blind), the success of these efforts are tenuous at best and just end up delaying the final demise of the business.

\section{Summary and Conclusions}

As we have seen, even though small family businesses make major contribution to our economic system, both financially and in employment, they face extraordinary risks and are not necessarily prepared for life-changing events, which significantly increase the probability of demise of these economic engines. Of course, these 
events (sudden death in the family, divorce, and major illness or a disabling accident) are major enough that they will have a significant impact on our lives, whether we are part of a family business or not. However, when these events happen to owners of family businesses, their impacts are amplified and endanger the viability of these businesses, with implications for our economic system. Therefore, as academicians and researchers, we should make every effort to study and understand the broad implications of these events and the characteristics of these businesses to find ways and educate the owners so that they can be somewhat prepared to tackle these challenges. Unfortunately, because of the ownership characteristics, daily business demands, and the unpleasantness of the subject matter make it a challenge for us to accomplish these objectives.

In our attempt to start a dialogue and encourage increased research in these topics, we started with a basic hypothesis which simply says "family business continuity requires a timely and planned transition of ownership and management from generation to generation. Any disruption which brings a crisis based transition will have significantly negative consequences on the business and will severely accelerate its demise." To test this hypothesis we developed three propositions and studied 30 family businesses. The summary of our findings are listed below. Our findings show that the issue is much more complex than our hypothesis and the impact of even a "life-altering event" is tempered by many other factors and do not necessarily result in closure of an ongoing operation. Of the thirty firms we studied, 17 of them $(57 \%)$ continued to operate by the same family members and 13 of them $(43 \%)$ were closed or sold to others. These findings are very hopeful and show that family businesses are not necessarily as fragile as we assume and these businesses can survive even the most devastating circumstances. In fact, the parents' unwillingness to give up control and authority at the time the next generation wants it or should have it and the next generation's lack of readiness for their responsibilities when they have to assume them may be a much greater problem than the impact of "life-altering" we studied. NFIB findings show that forty-eight (48) percent of family business owners would like to have a family member eventually take over operation of their venture. However, just 13 percent believe it is "very likely" that a family member actually will take over and another 23 percent believe it is "likely." However, the findings also show that only 7 percent of all operating businesses were inherited. (Dennis, 2002) (Table 4) 
Even though our findings show that there is a significant probability that the "family business" will continue to exist and operate, albeit in some damaged fashion, the danger is very real and these 3Ds or "unexpected life changing events" can have devastating effects. Therefore, as we consult and work with these family businesses, we have to alert them to these dangers and recommend some immediate approaches and preventive activities, and help them get prepared to deal with not only planned transitions but, unexpected ones as well. Of course, the most important preventive action, especially for "sudden death" and incapacitation/disability due to "major illness or an accident", is to have a well thought out succession plan, a plan to transfer managerial responsibilities and possibly ownership. Selecting and grooming a successor is best done when the owner is fully engaged in the business and can provide the necessary guidance and help with the eventual transition of leadership.

There are also some legal options and remedies to help with the contentious turmoil which generally is a side effect of "divorce". Among these legal actions are buy/sell agreements which give family members preference over outsiders, a non-biased mechanism which generates a valuation of the business on a periodic basis, and an explicit agreement which clearly defines the future of the business and possible predatory competitive activities of the ex-partners after the divorce.

Finally, there are the insurance policies. Even though the cost of these policies may have a significant impact on the cash flow and other financial resources of the family business, they provide an excellent resource to overcome some of the significant financial impacts of death of the owner (or one of the partners) and an incapacitating/disabling accident or illness. These life and health insurance policies (key-man policies) are a necessary and vital to the economic survival of the family business and are a legitimate cost of doing business. In addition to the "key-man" policies, given the financial resources of the family business, "business overhead expense" policies and "disability buy-out" policies (to buy out the disabled partner) can be very valuable and can be vital to the survival of the family business, after a "life-altering event". 


\section{References}

"War of the Zackses: Divorce Splits Up Mom and Pop Store ---In a Double Exposure, Exes Run Rival Camera Shops; Patrons Are feeling Uneasy, Hilary Stout." Wall Street Journal (Eastern Edition), November 12, 1997. pg. A1.

"Estate planning: Surviving an owner's death." Inc, 1 Apr. 1993, Vol.15, Issue 4; Pg. 45.

Barach, Jeffrey, Joseph Gantisky, James Carson, and Benjamin Doochin, (1988). "Entry of the next generation: Strategic challenge for family business." Journal of Small Business Management Vol. 26, No. 2, pg. 54.

Birley, Sue, Dennis Ng, and Andrew Godfrey, (1999). "The Family and the Business." Long Range Planning, Vol. 32, No. 6, pg. 598-609.

Dennis, W. Jr., (2002). Families in Business: NFIB National Small Business Poll, Vol. 2 Issue 6, 2002

Fritz, Roger (1997). Wars of Succession: The Blessings, Curses and Lessons That Family Owned Firms Offer Anyone in Business. Santa Monica, Calif.: Merritt Publishing, p. 250.

Galbraith, Craig S. (2003). "Divorce and the Financial Performance of Small Family Businesses: An Exploratory Study." Journal of Small Business Management, 2003 41(3), pp. 296-30

Hill, Kirk S. (1992). "Business Can Get Sick Too!" Life and Health Insurance Sales, July 1992. Vol. 135, Issue7: Pg. 4-5.

Janjuha-Jivraj, Shaheena and Adrian Woods, (2002). "Successional issues within Asian family firms: Learning from the Kenyan experience." International Small Business Journal, Vol. 20, No. 1 p. 77.

Kickham, V.F. (2004). "Keeping the Family Business Alive," Industrial Distribution, 11, pg. 48-52.

Lansberg, Ivan (1999). Succeeding Generations: Realizing the Dream of Families in Business. Boston: Harvard Business School Press

Lee, K.S., G.H. Lim, and W.S. Lim (2003). "Family Business Succession: Appropriation Risk and Choice of Successor," Academy of Management Review 28(4), pg. 657-666.

Livingston, Abby (1997). "Make your Family Business Divorce Proof." Nation's Business, January 1997. Vol. 85, Issue 1; pg. 64-65 
Martensen, Jon (1995). "Facing Death gives birth to business." Small Business News, May 1995. Vol.2, Issue 1; Sec 1. pg. 10.

Miller, Danny, Lloyd Steier, and Isabelle Le Breton-Miller, (2003). "Lost in time: Intergenerational succession, change, and failure in family business." Journal of Business Venturing, Vol. 18, No. 4, pg. 513.

Montgomery, B.J., and A.M. Sinclair (2000). "All in the Family," Business \& Economic Review, Jan-Mar., pg. 3-7.

Poza, E. J. (2004). Family Business, Mason, OH: South-Western

Sporss, Kelly K. (2007). "Keep Business Alive With Succession Plans." Wall Street Journal, (Eastern Edition), August 5, 2007. pg. A1.

Stavrou, Eleni T. (1999). "Succession in family businesses: exploring the effects of demographic factors on offspring intentions to join and take over the business." Journal of Small Business Management, V. 37 no. 3 (July 1999) pg. 43-61

Weikart, Richard J. (2001). "Protecting small-business owners." Advisor Today, January 1, 2001: 14. 